\title{
Online Disinformation in the Run-up to the Indian 2019 Election
}

\begin{abstract}
This essay examines the role of disinformation in the Indian general election of 2019. The findings are presented against the background of previous work on the role of digital media in Indian politics. The essay uses 25 in-depth interviews among ordinary Indians to probe their level of awareness about so-called 'fake news'. It also examines their behavior in seeking news and sharing political information and their views about the digital campaign strategies of leaders and parties. The interviewees were concerned about the increasing role of religious extremism online. Yet they were also strongly aware of the role of disinformation campaigns and had strategies for working around being misled by information shared on social media. The essay concludes by assessing how disinformation and online extremism are likely to have affected the 2019 election, and makes comparisons with Modi's election in 2014 and with other leaders.
\end{abstract}

\section{Introduction}

The Indian national election was held in April/May 2019 in which The Bharatiya Janata Party (BJP) won 303 seats and the BJP-led National Democratic Alliance (NDA) won 353 seats. The Indian National Congress Party (NCP) won 52 seats and the NCP-led United Progressive Alliance (UPA) won 91. Other parties and their alliances won 98 seats. Kerala, the base of our data collection, is one of two major Indian states where the NDA did not win a single seat and the UPA won 19 of 20 seats (India Today 2019). The election took place against the background of widespread concerns about the role of social media in the spread of disinformation. These concerns have received extensive discussion in the media and in academic research since the Brexit referendum in 2015 and the election of Donald Trump in 2016, often under the label of 'fake 
news'. Another part of the background to this election are Narendra Modi's extensive and skillful uses of social media, which are widely regarded as having helped to bring him to power in the 2014 election (for example, Price 2016). Modi's media strategy and his politics have also been described as populist, communicating directly to his supporters and promoting an extreme version of Hindu nationalism (Jaffrelot 2015).

In this essay, we examine disinformation and role of news and digital media in politics through the lens of 25 in-depth interviews. The essay is organized as follows: first, we provide the background to the role of digital media in the election, focusing on previous work about India. The next section briefly documents the method of our interviews. Then we present our findings, followed by a discussion which draws out some themes from the interview material. We conclude with reflections about how the views of Indians may affect their political behavior and their media uses and how digital media shape the prospects for India's democracy.

\section{Background}

Studies of the role of computational propaganda have been carried out for many elections and parts of the world (Woolley and Howard 2016). A overview of the role of 'fake news' said that 'concern over the problem' has become 'global' (Lazer et al., 2018: 1094), although for Trump's election in 2016, a comprehensive analysis (Sides, Tesler and Vavreck 2018) concludes that the role of social media was not decisive (see also Grinberg et al. 2019). Be that as it may, the debate over the role of Facebook, Google and Twitter in elections continues to be much discussed, both among academics and in the media. 
A review of the extensive literature on digital media, disinformation and politics is outside the scope of this essay as the focus here is on India. For India, the use of the internet in politics has received scant attention compared with the US and other countries, partly because its advent is more recent. Indeed, the first time this topic received major attention was with Modi's campaign in 2014 when he became prime minister. The closest analogy to Modi's campaign was Donald Trump's campaign to become president: both Modi and Trump used Twitter in particular to circumvent the opposition they faced from within their own party to their candidacy, as well as from criticisms they faced from traditional - in Modi's case especially elite English-language media. Modi gained an advantage by relying instead on the more widespread vernacular, and especially Hindi, language media, as Neyazi (2018: 161-185) has convincingly argued. Further, Modi, like Trump, used Twitter to criticize and belittle his opponents, and especially Rahul Gandhi - the leader of NCP.

Modi was not the only one to benefit from Twitter. Ahmed et al. (2016) analysed a large random sample of tweets from all of the major parties during the national election. They found that the internet (and especially first- time voters, who are more likely to use mobile phones and the internet) played a crucial role in the BJP's success. The party that had the next greatest Twitter presence was a relatively new and small challenger party, the AamAadmi (common man) Party (AAP). Nevertheless, Neyazi, Kumar and Semetko (2016) found (for three urban areas) that party contact face-to-face and by phone were the two most important predictors of political engagement during the 2014 election, ahead of online media attention. 
In terms of Modi's media strategy, Pal et al. (2018) showed that his Hindu nationalist appeal via digital media was stronger before he began his national election campaign. During the campaign and after he became prime minister, he had to reach out to all faiths. Now that he is in power, he regularly tweets greetings during the religious holidays and festivals of other religions. Still, Modi’s 2014 campaign can be described as populist. Jaffrelot (2015) labels Modi's campaign 'high- tech populism', an appeal particularly directed at a younger urban elite and befitting his campaign promise to take India into a digital future. The campaign also focused on Modi as a leader rather than on his party, and he has personalized his campaign further by posing with Indian spiritual leaders and Bollywood and cricket personalities (Pal et al. 2016).

Pal et al. (2016) document how Modi used Twitter to energize his followers in the RSS (the RashtriyaSwayamsevakSangh, a large Hindu extreme right-wing nationalist volunteer organization, see Andersen and Damle 2018), who were grateful when their leader mentioned them in a tweet. Bajaj (2017), in contrast, coding the 'frames' of Modi's tweets during the 2014 election campaign, finds relatively few tweets with the Hindu nationalist message of the BJP while most of the tweets advertise his agenda of economic development. Gonawela et al. (2018) took a different approach: they compared the tweets of Modi, Trump, Geert Wilders (Holland) and Nigel Farage (UK) for several months during the respective elections of these right-wing populists. Trump's tweets are far more negative than Modi's and he tweets more personal insults and criticisms. In contrast, Modi engages in more wordplay and tweets more group insults, for example, by bundling criticisms about several Congress politicians or the Gandhi family into one tweet. 
After the election, Pal says that 'most of Modi's tweets, have become banal, feel-good messages, shout-outs to major events and popular figures, and nods to partnerships and affiliations' (2015: 386). Pal et al.(2017) coded Modi's tweets from the beginning of his account in 2009 until 2015, noting, among other things, that his sarcastic attacks practically disappeared after he was elected and his tone became more positive and aspirational. Finally, Chakraborty et al. (2018) examined how Modi's tweets translate into traditional media from 2009 until 2015 in three major English language outlets - The Times of India, The Hindu, and the NDTV website - although they note as an aside that Modi has more followers on Twitter than the audiences of all of these outlets combined. The authors make the important point that instead of social media being used as a tool to disseminate news, news now originate in social media and thus get attention in traditional media. This is no accident: Modi is the first Indian prime minister to completely avoid press conferences (see, for example, The Wire 2018). At the same time, digital media are only one channel by which he communicates: he also has a weekly radio programme, Mann Ki Baat ('Speaking your mind'), which lasts for half an hour and reaches 40-50 million listeners mainly in remote rural India (Livemint 2014). And apart from election campaigns, there are other ways that people make use of digital media to discuss politics: Punathambekar (2015), for example, describes some of the humorous and satirical videos that went viral during the 2014 election.

While there has been research about digital media uses in politics, the role of disinformation in Indian politics has received very little attention, unless hate speech is included within its ambit. George (2016) includes an analysis of India in his book about 'hate spin' and Udupa (2015) has focused on Hindu nationalists. More recently, Mirchandani (2018) has analyzed hate speech on politics-related Facebook pages. She found that hate-related comments closely follow divisive 
political events. But disinformation as a topic post-dates Modi's 2014 election, and has become more prominent recently.

Finally, a brief note on terminology: we will use 'disinformation' to describe political messages that mislead or try to confuse the public. 'Misinformation' and 'propaganda' are also used in the academic literature (and by our interviewees), but this indicates more systematic attempts or deliberate efforts to spread lies to advance a specific agenda. 'Social media' is used for social network sites such as WhatsApp, Facebook, Instagram, Twitter and TikTok where there is group or follower/followee interaction (the first three were common among interviewees, though Instagram less so among older interviewees, TikTok only among a few younger ones, and Twitter mostly passively among a few). But we also use 'digital media' to refer to all online activity, including searching on Google, watching YouTube videos, and using apps and reading newspapers online.

\section{Method}

For this study, we interviewed 25 people in December 2018 and January 2019 by means of the purposeful snowball technique through whereby we gauged opinions of a population that is heterogeneous in terms of age, gender, religious faith, and political ideology. To do so, we purposely sampled from among the supporters of different parties, including the BJP, NCP Communist Party. Interviews were between half an hour and forty-five minutes long and consisted of 33 questions, eight of which established their background and the remainder concerned politics and digital media (see appendix 1, the questions about privacy and the Aadhaar system are peripheral to our concerns, and so left out below for reasons of space). The interviews were 
recorded and transcribed. Consent was obtained under [university name removed for review] research ethics guidelines and all quotations below are pseudonymised (see appendix 2 for information about the participants).

One limitation of our paper, however, apart from relying on interview data, is that our sample of interviewees was biased towards people we could reach via snowballing, and the majority of interviews (apart from two, who were from Ahmedabad in Gujarat) were with people currently living in Kerala, although most had also lived outside the state. Kerala has rather special social and political circumstances, including a history of Communist parties dominating government since Independence. Indians are well-known to be avid newspaper readers (Jeffrey 2000), including among the least- well-off groups of society. Kerala is also rather special in that there is almost universal literacy. And our interviewees, as we shall see, even those less interested in politics, were avid consumers of news.

Our interviewees were also skewed in terms of education, with all having at least an undergraduate degree and several having postgraduate degrees. Interviews were also carried out in English. This means they are unrepresentative of India's population. We can also guess, however, that for a rural and less educated population and with interviews carried out in local languages, most of the questions regarding national politics, the spread of disinformation in digital media and views of how the current prime minister uses media - would have made little sense. Though they would have had views about the government and of the prime minister, the $60 \%$ or so of the population that uses basic phones or no phones might have found questions about political disinformation or digital media and politics irrelevant or confusing. A recent survey by the Center for Developing 
Societies (Livemint 2018) puts the share of WhatsApp users among the upper middle class and rich (the highest quartile) at $45 \%$ while it is only $14 \%$ among the poor (the lowest quartile). Among the urban population WhatsApp use is at $38 \%$ and among rural users $20 \%$, and this is also heavily skewed by age, with almost half (49\%) among those 18-25 but only $7 \%$ among those 56 and older. The population in Kerala is also exposed to disinformation in social media both through English and one or more of the regional languages (i.e., Malayalam, Hindi, and Gujarati).

The transcribed interviews were analyzed by developing a schemata that surfaced different themes in the interviews (this was done by two coders who examined the interview material). Figure 1 presents this categorization. In case of disagreement, a third member was consulted to resolve the dispute.

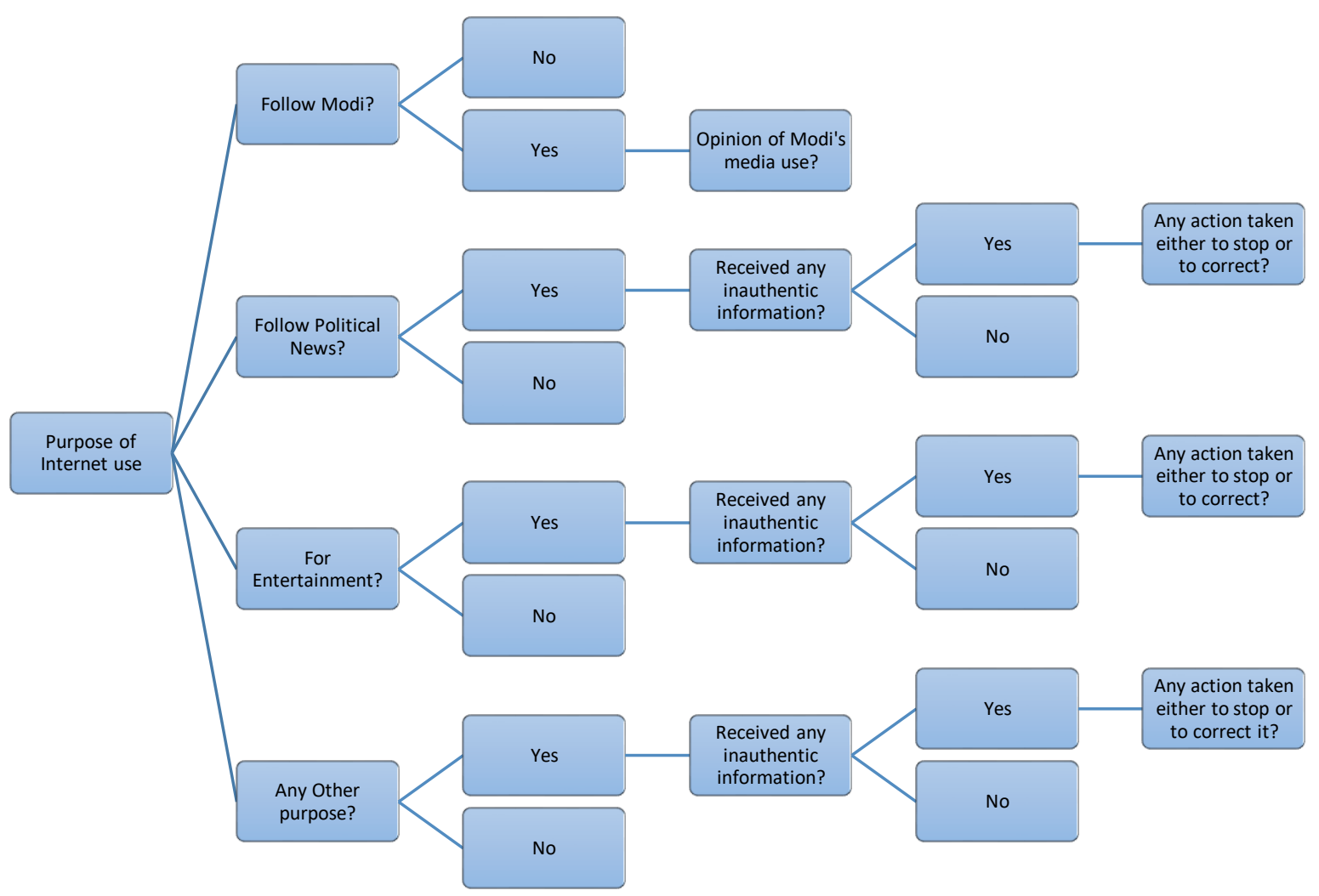

Figure 1. Data categorization scheme 
In the Discussion section below we will provide further detail about the substantive themes that emerged from this categorization, which includes the role of religion, the understanding of disinformation, the role of social media, and Modi's use of media. In that section we also provide a sense of some of the commonalities and differences among our interviewees. Before that, for the sake of clarity, we have chosen in the following section to present the quotes from each of the interviewees separately: This allows us to give a sense simultaneously of the background of the interviewees and how this fits with the distinctive parts of their views. We present only 18 of 25 interviewees as some responses overlapped and were repetitive and we had evidently reached saturation among the limited groups that we targeted with our snowball strategy.

\section{Findings}

Religion often came up in relation to disinformation. Priyanka, a 33-year old bank branch manager and Christian told us that her main political concern, apart from corruption, is that the government should be more secular. She gets messages in her Facebook newsfeed, for example about the politics of the Sabarimala temple dispute (a contentious issue concerning whether women should enter a Hindu temple which was extensively covered in Indian and international news media during our interview period), taking both sides, but she would always 'take them with a pinch of salt'. Like others, she also had stories about 'fake news' during the Kerala floods in the summer of 2018, such as a message in a WhatsApp group about a supposedly poisonous insect that should be avoided: it was only through a colleague from the countryside that she found out not to take this false story seriously. Still, on the whole she remains pleased with what the internet has to offer, finding particularly useful a WhatsApp group for young mothers (she is a mother of a three-year old) and apps that provide cooking tips. 
The views of a strong Modi supporter are well-illustrated by Vidya, a 59-year female retired teacher and devout Hindu. In typical populist fashion, she thinks media are biased against Modi, including television and newspapers. Like others on the right (but also some on the left), she distrusts Congress ('why should we have a family of looters?'). Yet she discusses politics on WhatsApp and Facebook only with 'like-minded' others. She also subscribes to the NaMo app (news from Modi) and follows him on Twitter, regarding these as trusted sources of political information, in contrast with traditional media which, in her view, favour the opposition. She gives as one example of 'fake news' when the prime minister visited Orissa, and 'news' was circulated that 1000 trees had to be cut down to allow him to land - an example of video propaganda spread via social media. And while she thinks secularism has gone too far and religious expression (Hinduism) should be strengthened, this strengthening should not come at the expense of other religions ('mosques are not wrong'). And despite espousing outspoken political views, her main online activities are related to cooking and finding material related to spirituality. She also spends time volunteering at an orphanage for girls, and so is a civic minded citizen.

Yet it is not just social media that spread 'fake news' about Modi but also traditional media, at least according to Siddarth, a 69-year old Hindu and semi-retired businessman. Like several of the BJP supporters among our interviewees, he thought India's standing in the world had improved with Modi. But he mentioned a recent widespread story about how much Modi was spending on foreign trips. The purpose of these stories, Siddarth said, is to 'tarnish' Modi since, even if true, the media should focus on policies rather than on foreign travel - which costs a lot for all politicians. Modi, in his view, 'is the only prime minister who has connected with the electorate', 
for example with the NaMo app (which, like Vidya, he subscribes to) and the Mann Ki Baat programmes. And though a Hindu and supporter of Modi's strong leadership - having to share power among coalition partners or regional parties would weaken the government, in his view he thinks religion should be kept out of politics: instead of issues such as the Sabarimala temple, Modi and the BJP should focus on economic development, which 'everyone wants'.

A 54-year old Hindu and former naval officer and now businessman, Pronobesh is also worried about too much religion in the media, pushed by politicians and parties. This is 'harmful' in his view. As with the businesspeople among our interviewees, he thinks special interests, like those of religious and other minorities with special status, are harmful to stronger national economic development. In this respect, although he would not vote for Modi, he sees him as a 'bold' leader and beyond corruption, even if those around in him in the party may be corrupt.

Shriram, a 33-year old doctoral student in marketing with no religious affiliation (calling himself an 'agnostic') had voted for the BJP in 2014 but was now inclined to vote for anyone but the BJP: although he regards Modi as an 'awesome marketer', he also thinks that he has made mainly empty promises. His main source of news is the aggregator Inshorts App, which provides 60 word snippets which then link to stories. His main worry is about how 'loud' politics has become in the media, with too many opinions and too many political posts shared in WhatsApp groups. In his view, politics since 2014 has become too religious, 'that scares me...moral policing'. Among the examples of disinformation spread on social media he mentioned the student arrests at the progressive JNU university and child abductions, both covered extensively in the news but also 
with many false stories circulating on social media. Yet Shriram also mentioned that there are many fact checking sites to discredit these false stories.

An illustration of someone who is trying to ween himself off social media is Bharath, a 26-year old Hindu MBA student. He had spent a lot of time on Facebook but quit, and now concentrates his social media use on WhatsApp for personal purposes and Twitter for information. Indeed, he now uses Twitter 'more than I should' because he follows prominent people who give investment advice and tweets about them. And like others, he is worried about people sharing fake news on WhatsApp, and mentioned doctored videos from the JNU events. The media are biased in his view, for example they 'don't cover the good work being done by the Aam Aadmi party'. In his view, there is too much media censorship and fake news spread by the government, and 'people are fearful, scared, because of extremism' that is fanned by the media.

Similarly Aasim, a 26-year old Muslim engineering student, who is concerned by religious extremism on both sides, Hindu versus Muslim as well as Congress versus the BJP. He supports Congress and said he cannot support some conservative Muslim politicians and their views on restricting women's rights, citing the Sabarimala temple issue: in the US, he said, Muslim women can attend mosques, and 'everyone should be allowed to go'. Still, he is aware that other Muslims have different politics, for example in his hometown of Lucknow where Muslims are strongly conservative, though mostly via Friday prayers where they get their ideas from the head of the mosque. In his view, much news is distorted online, giving the example of the claim that the BJP had electrified $100 \%$ of the country: even if true, much of this had been achieved before the BJP came to power. Similarly, false news is being spread about riots, lynchings and the like: 'my Dad 
will forward anything', he says. But all parties exploit religion, for example in relation to the contention over the Babri Masjid religious site (which has been a major contentious issue between Hindus and Muslims since the 1990s). Still, he would 'like to believe Modi is a good man', but others around him 'use his authority to do bad things'.

Nabila, a 26-year old Muslim civil engineering student, also considers the prime minister as skilled in communicating his message, but she thinks that 'he has not fulfilled the dreams of every Indian'. She favors religious freedom for all and regrets that the Modi government promotes 'communalism'. She gets information about what is happening in Kerala by following the Chief Minister of the state on his Facebook page and in this way stays updated about his policies. Kerala is known for having achieved greater gender equality than other Indian states, and Nabila thinks that 'more recognition should be given' for women (the phrase 'more recognition' is often heard in this context, and a contrast is made with the North of India, where women are more unequal and so not 'recognized' as they should be). She has only a limited interest in politics and mainly uses the internet for entertainment such as music on YouTube and shopping online. Yet 'women's issues' is something she follows online, citing the rape and murder of women as issues she comes across. Women 'want equality', she says, 'but that is not possible in a patriarchal society'.

But again, there is also a positive side to social media, at least according to Sarabjeet, a 58-year old Sikh public sector employee from Ahmedabad. He applauds the recent strengthening of nationalism that has given a sense of 'belongingness' to Indians and thinks that social media 'provides a way to connect with the masses'. Yet he has nevertheless been worried about 'fake' 
information: 'they keep on coming...you don't know the source', adding 'every party...does this business'. The news cannot be trusted, he says, 'some TV and newspapers are from the business classes', but 'the public cannot be fooled, they know which is owned by whom'.

Gautam, a 52-year old Buddhist who works in the public sector as a geologist in Ahmedabad, has developed a strategy for overcoming the untrustworthiness of the news; to check veracity, he says, you need to 'google it'. Since his main source of news is TV, he had switched from Republic TV, the BJP supporting news channel with the largest audience share - 'the anchor hurts me, speaking so much' (Republic TV has a very vocal anchor) - to Mirror Now, a channel that he can trust more. But in WhatsApp groups, the only social network he uses, in most groups he is part of political messages are spread that cannot be trusted; ' $10 \%$ are authentic news, $90 \%$ are fake news'. He 'trusts Google more than WhatsApp' since he can find 'authentic sites' this wa. There are many rumors about politics, he said, but if you 'google it, you find none of' these rumors. In the election, he searched for a party to support since he likes neither the BJP nor Congress: he had had 'high expectations' for the BJP, but 'things should have been done' and it 'should have concentrated on corruption'. Yet he is disappointed with the results.

Another interviewee who is not happy with how the BJP has failed to live up to its promises is Geetika, a 24-year old Hindu Master's student in engineering. Once parties and politicians are elected, she says, 'they are less concerned'. She 'gets notifications' via all the social media she uses, which are Facebook, WhatsApp and Instagram. But these notifications 'won't give right information about the content'; in other words, they tend to have misleading tags or headlines. As a Kerala native, the main recent political issue on her radar has been the Serabimala temple, which 
she thinks 'will be resolved. We are in an early stage, let them [the women] enter'. Although she is not very interested in politics, she receives 'fake news' in her WhatsApp groups, such as a recent message that the United Nations had selected the Indian national anthem as the best in the world, a false story that was widely circulated. But she would not correct such messages since they might be circulated by people like her uncle, so it would be rude to do so. She also obtains information about politics from satirical TV programmes and on YouTube, which make fun, for example, of the BJP's response to the issue of how cows should be treated - another issue that has recently become contentious with Hindutva politics - or of the prime minister's foreign trips.

Aditya, a 22-year old Hindu engineering Master's student from Andhra Pradesh who is not very interested in politics, uses as his main source of news the app 'Newsdog', an aggregator with short stories. He stressed, however, that information must be 'googled' before it can be trusted. He is member of four or five WhatsApp groups, mainly with other students, but 'ignores' the rumors that are circulated there. His main online interest is entertainment and he comes across political debates and videos making fun of politicians on YouTube and Facebook. Political messages as such, he says are 'rare'.

It is quite different for Alladi, a 23-year old Hindu engineering Master's student from Andhra Pradesh, who has a strong interest in politics. He is from a rural area and supports the recently formed progressive Janasena party, only active in Andhra state and led by the famous Telugu film star Pawan Kalyan (film stars who go into politics are common in Southern India). His main source of news is the app 'DailyHunt' but he also follows Janasena on YouTube and Facebook. His main concern is with Andhra rather than national politics, but here, too, he says, TV and newspapers are 
biased, and so digital media are a useful for staying informed. He thinks politicians and parties that use digital media can be positive; 'it's good to communicate what they are doing', including the prime minister, whom he does not support. Modi's messages on social media can, in his view, be trusted.

Sudhir, a 45-year old Hindu IT entrepreneur who voted for Congress in 2014 but is inclined to vote for BJP in 2019, said he gets lots of 'fake news'. He gave the example of a WhatsApp group link that was shared consisting of a video clip where a Hindu guru is taking a stance against women entering the Sabarimala temple - as we have seen, a contentious recent issue. But the clip in fact showed the guru quoting others taking this stance, whereas the full clip in fact showed him taking quite a different position. It had obviously been edited to spread this distorted picture, and Sudhir said '95\%' of news in social media is of this type. He checks this kind of information and in this case also found the real video on YouTube and Facebook and tries to make others aware of this kind of 'propaganda'. Still, in his view 'the majority of people' would be fooled by it.

An example of a Muslim who thought that the online environment had become 'uncomfortable' under Modi is Amir, a 45-year old developer of educational software. Even earlier, he argued, since the 9/11 New York bombing, Muslims had wrongly been branded as terrorists. In his view news media have become too 'distorted' and negative and Modi uses social media 'too much'. He said that he has gotten bored of getting emails from the prime minister and started questioning the achievements highlighted there. Yet he also uses social media in a positive way and has started a Facebook page for organic farming, a personal hobby, which has attracted 'a few hundred' followers. 
Someone who has been very active online as a student on behalf of the BJP is Anesh, a 28-year old Hindu from Bihar. He had often spread messages online that would make fun of Rahul Gandhi, for example. But he has stopped now because he runs a small business and might get a bad reputation from online politicking. It might also be a 'waste of time' because of the lack of impact. Still, he receives lots of political messages, especially in his WhatsApp groups. Among them was a shared message which contained, side by side in two columns, three rows of images of sets of male and female brother and sister goddesses. Underneath these, in a fourth row, were images of Rahul Gandhi and his sister Priyanka Gandhi (she had just been appointed in a high profile role to support the Congress campaign), with the caption 'brothers have always used their sisters to target the enemy'! Around this time, there was lots of speculation about how much of an asset Priyanka would be to her brother who is regarded by many as a weak leader. And although he supports Modi, he is worried that the prime minister did little to stop or disown people like Yogi Adityanath, the extreme right BJP chief minister of Uttar Pradesh, and others from fanning religious hate or the online spread of messages about lynchings and beef bans.

Ali Reza, 26-year Muslim university teaching assistant is also worried about growing religious intolerance. There used to be 'freedom to eat anything', he said, whereas now bans on eating beef are promoted, especially online. He also described an online portal, run by a businessman from Kerala but living in the UK [http://www.marunadanmalayali.com/, Shajan Skaria], in Malayalam language, which has deliberately spread disinformation in order to profit from advertising. In some cases the site has even been used to blackmail businesspeople in Kerala into paying money lest compromising (false) information is posted about them on the portal which could ruin their 
reputation (Skaria has been fined in the UK for these activities). Ali Reza had received much false information online with 'catchy captions' which turned out to be not what the headlines advertised. He had also been asked by all the major parties - Congress, BJP, and, as a Keralite, the Communist party - to volunteer for them in the 2019 election on Facebook by 'sitting at home and working for us'.

Finally Mahsah, a 25-year old Muslim working as an administrative assistant at a university, considers Modi to be 'cunning' and able to 'manipulate' people online. Her own political engagement has been progressive, particularly in light of her humanities and social sciences education. On Facebook, she said, there is a lot of 'patriarchal moral policing' in her extended family and beyond, with people telling her that she is 'not part of the community' of Muslims and should wear the hijab. These criticisms are due to her outspoken feminist and leftist views and have come mainly from her cousins and extended family. Her parents, in contrast, who are from modest circumstances, have been very supportive of her views. She also evades potential criticisms among likeminded friends in her Facebook groups by 'using fake ID's', which gives them 'the space' to speak their minds openly within their closed circle about political and gender-related issues. She advocates a 'rooted' feminism, regarding some forms of feminism as 'too elitist' or 'too American'. She believes that politics and gender attitudes should instead be changed at the grass roots level, and has worked and volunteered with illiterate and school age youngsters to this effect.

\section{Discussion and Conclusion}


It is apparent that despite the wide variety of views about digital media and disinformation among our interviewees, there are also some common concerns and new ways of dealing with information sources. Figure 2 presents the themes that emerged in the patterns of how the participants addressed the issue of disinformation which we will now elaborate further.

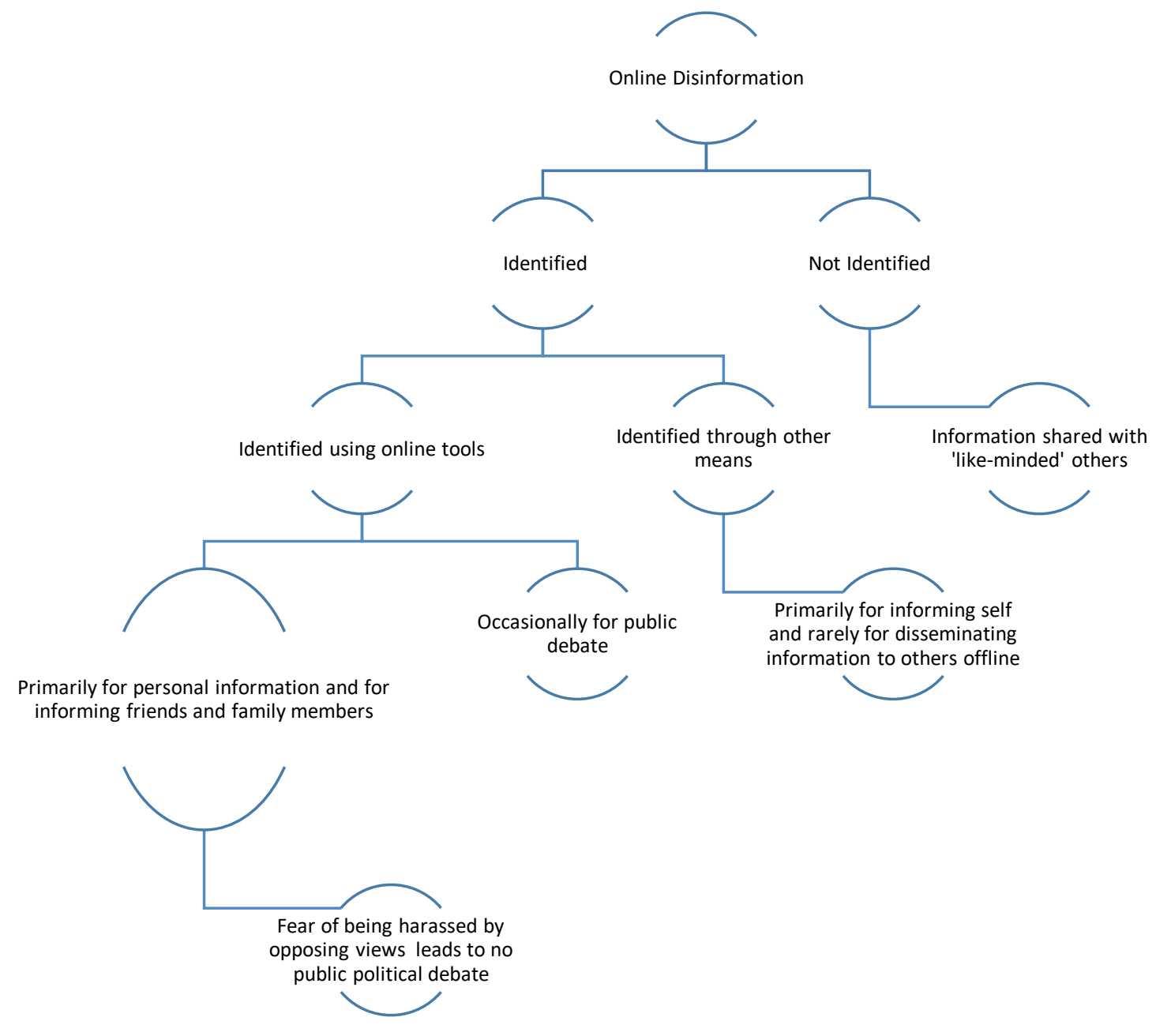

Figure 2. Patterns in identifying and addressing online disinformation.

In 2014, the election was top-down in how digital media were used in the election campaign in the sense that Modi used Twitter in particular to circumvent traditional media and his own party. His campaign also used digital strategy consulting firms to boost its messages to voters. In the 2019 election, in contrast, digital media were used in a more bottom-up way, with messages being spread in WhatsApp groups, for example. Unlike in 2014, all parties now use digital campaigns to spread 
messages and target voters. Put differently, in 2014, Modi could appeal to his supporters directly; in 2019, it seems people have become more skeptical, even as heralding his achievements has become his main activity on Twitter. As ever, incumbent politicians are judged partly by how much they have lived up to their promises.

Amidst a general skepticism about governments past and present, there is nevertheless a strong faith in India's democratic institutions and in the need - if not the reality - of the public to hold politicians, parties and governments accountable. Most interviewees said that what they valued about Indian politics and media is that different voices could be heard and can make a difference. What they most disliked about digital media generally is that too much time is spent online and that some people seem addicted (indeed, the word 'addicted' came up among several interviewees, mostly in relation to others, but with some also saying that they had tried to cut down on digital media use). Interviewees are mostly careful to express their opinions or share material only with like-minded others. This fits with the ethnographic finding of Venkatraman (2017) that in the private sphere of family and friends, people mainly share political views to enhance their own status and make fun of politicians. The exception to sharing views only with like-minded others are those engaged in political activism, not necessarily in the formal sense but in the sense of promoting certain political views in their social media groups.

Again, interviewees generally felt that they should avoid discussing politics where this is likely to cause conflict with others online; they felt that there is no point to these discussions since people were not there to debate and learn but instead to push their own entrenched views. Yet there are clearly growing concerns about the spread of falsehoods online, which is seen as a threat to a 
properly functioning news environment and government. Still, there are degrees of this concern and most interviewees also thought that the media play a positive role. Yet in India, it is also widely believed that media ownership makes the media biased in favoring particular parties or political viewpoints. BJP supporters in particular, like populist supporters elsewhere, furthermore felt strongly that the media are biased against Modi, paid by anti-Modi interests and spreading falsehoods about him.

Modi is nevertheless commonly seen as a strong leader and a savvy media user and 'clean' - in contrast to the Congress which is seen as a family that has 'looted' the country. Modi's uses of social media can be seen as populist insofar as he uses a direct communication style to appeal to his supporters (Moffitt 2016). This has been successful since even those who oppose him regard him as a masterly user of social media. Interviewees were aware of the prime minister's digital media use, but also aware that this is mainly a one-way tool for him. Some of his erstwhile supporters and his detractors had become more skeptical of him over time and were now judging him more on whether he had lived up to his promises. Here it is worth stressing that interviewees were highly aware of the debates around political misinformation ('fake news') and well-versed in current affairs generally.

Among our educated interviewees, how religion is treated in the media is mainly seen in a negative light: although devout, and mostly Hindus, our interviewees talked freely and without prompting about how religious extremism has been a growing problem in India - though this is so mainly online, and not so within their own offline circles. The problematic nature of online religious extremism has been covered extensively in the news in India. And our interviewees had plentiful 
such items in their social media feeds, though for the most part they chose to ignore them. It seems that the religious divisiveness online that is much discussed does not come from the majority of people themselves. Instead, the sources of these circulated messages are politicians and parties and religious groups. There are exceptions, however: a small number of the interviewees felt strongly about religion and themselves circulated political and religious messages - or in even fewer cases circulated messages to counter extremism and disinformation.

Growing religious extremism is clearly regarded by out interviewees as one of the main political issues facing India today, alongside corruption, economic growth and widening social inequalities. There are fears and concerns over the extent to which religious conflict is increasingly being stoked online. In this respect the differences among our interviewees are mainly a question of degree, with some variance also according to which group is expressing this concern, Muslims being most upset. More generally, as Chhibber and Verma have shown in relation to the 2014 election, 'those who are more exposed to media are more ideological'(2018: 161) on the scales of the role of the state and the religious politics of recognition. Apart from growing religious intolerance, the discussion of politics was dominated during the timeframe of our interviews by a few key issues. These included the recent demonetization and the introduction of a general sales tax and the ongoing dispute about women entering the Sabarimala temple in Kerala. The fact that the temple issue came up frequently in discussions about social media disinformation lends support to the finding in Mirchandani's (2018) report about hate speech on Facebook; namely, that divisive issues tend to be strongly related to current controversies. 
The attacks via social media have continued. On January $31^{\text {st }}$, after most of our interviews were completed and the budget had just been announced, Rahul Gandhi called Modi 'The Fuhrer' on Twitter, to which the official account of the BJP (BJP4India) replied by calling Rahul Gandhi 'Mussolini'. Interestingly, Modi, who was in a position of power, mainly hails his own achievements on social media while leaving attacks to others. Challengers like Rahul Gandhi must attack Modi's record in order to tap into the disappointed promises that we saw among many interviewees. A brief comparison can be made here with Trump, who has also been in power for some time now, like Modi. Yet Trump still uses tweets to attacks his opponents and the media directly; but then, he is more embattled by opposition forces and by the media than Modi, who is predicted to be part of a winning coalition. It can be added here that our findings are broadly in line with the Reuters Digital News Report for India (Aneez, Neyazi, Kalogeropoulos and Nielsen, 2019: 20), which surveyed a sample of English-speaking urban internet users (as were our participants) at the same time as our interviews, and found that they had similar levels of concern with disinformation as in the US and Turkey, and that half of those surveyed were concerned about 'false' or 'fake' news, with no difference in the level of concern as between the supporters of different parties.

This leads to a general theoretical point: the aim of people's private uses of social media, except among those who can be described as highly engaged in politics or perhaps activists, is not to set the agenda, as politicians and media do. Rather, it is to exchange views and, in the case of activists, spread messages within their own circle as widely as possible. But clearly, there are those (like our interviewee Vidya, described above) who is a populist supporter of Modi and who thinks that the media are heavily biased against him. There are also others who seek out digital media rather than 
relying on what they think of as biased traditional media. However, circumventing traditional media blurs the distinction between gatekept professional media and digital media. Thus while contention in the public sphere aims at dominating the attention space (Neuman 2016), this aim has now been enlarged such that campaigns not only circumvent traditional media (as Modi did in 2014) but also encourage the spread of messages in groups. But while the strategy of circumventing traditional media, including with disinformation, was new during the 2014 election, in the 2019 it has become more routing, with social media more exposed to disinformation but also more aware of and managing this sharing of disinformation and circumvention of traditional media.

In this more diverse media environment, disinformation has become more central to campaigning. Yet it has also diminished in importance because of the high level of awareness, at least among our interviewees (as mentioned in the Methods section, again, a limitation of our study is that our interviewees were highly educated; among less educated ones, this awareness may not hold). The term 'fake news' readily and repeatedly came up in our interviews. Yet there is also a widespread and strong distrust of traditional media among our interviewees because of their bias, which is leading them to seek out and rely more on digital sources. The aforementioned survey by the Center for Developing Societies (Livemint 2018) says that news shared on WhatsApp and Facebook is mistrusted by $69 \%$ and trusted by $21 \%$ (with $10 \%$ no response), while half or more trusted TV (50\%) and newspapers (55\%) while $40 \%$ mistrust TV and 39\% mistrust newspapers (no response was $10 \%$ for TV and $6 \%$ for newspapers). In times of more distrust and more online disinformation, the onus is therefore not just on traditional media to preserve their autonomy and professionalism and on politicians to campaign honestly and in a civil manner - but also on citizens 
to manage their increasingly diverse news sources more actively and ensure that they are wellinformed.

Modi's and the BJP's populist strategy of fomenting religious nationalism online thus reinforces and is turn reinforced by a more diverse and no longer trustworthy media environment. This vicious circle can only be undone by restoring faith in objective journalism and in civil discourse on the one hand, and by resolving the tensions that give rise to populist politics on the other. It will not be undone by censoring digital media (though extreme hate speech should be regulated) or by non-populist parties copying the media distrust and the divisive policies of their rivals. India's democracy thus faces an uphill battle as far as digital media are concerned, but the awareness among our interviewees about the nature and extent of the problems also provides some grounds for optimism.

Aneez, Z., Neyazi, T. A., Kalogeropoulos, A. and Nielsen, R. (2019). Reuters Institute India Digital News Report, https://reutersinstitute.politics.ox.ac.uk/sites/default/files/2019-03/India_DNR_FINAL.pdf

Neyazi, T.A. (2018). Political Communication and Mobilisation: The Hindi Media in India. Cambridge: Cambridge University Press.

\section{References}


Ahmed, S., K. Jaidka\& J. Cho. (2016). The 2014 Indian Elections on Twitter: A Comparison of Campaign Strategies of Political Parties. Telematics and Informatics 33: 1071-87.

Andersen, W. \&Damle, S.( 2018). The RSS: a View to the Inside. New York: Viking.

Bajaj, S. G. (2017). The Use of Twitter during the 2014 Indian General Elections: Framing, Agenda-Setting, and the Personalization of Politics. Asian Survey, 57(2), 249-270.

Chakraborty, S., Pal, J., Chandra, P. and Romero, D.M. (2018). Political Tweets and Mainstream News Impact in India: A Mixed Methods Investigation into Political Outreach. In Proceedings of the 1st ACM SIGCAS Conference on Computing and Sustainable Societies (p. 10). ACM, June 2018.

Chhibber, P. and Verma, R. (2018). Ideology and identity: the changing party systems of India. Oxford: Oxford University Press.

George, C. (2016). Hate Spin: The Manufacture of Religious Offense and its Threat to Democracy. Cambridge, MA: MIT Press.

Gonawela, A; Pal, J; Thawani, U. van der Vlugt, U; Out, W. and Chandra, P. (2018). Speaking their Mind: Populist Style and Antagonistic Messaging in the Tweets of Donald Trump, Narendra Modi, Nigel Farage, and Geert Wilders. Computer Supported Cooperative Work (CSCW), 27:293-326. 
Grinberg, N., Joseph, K., Friedland, L., Swire-Thompson, B., \&Lazer, D. (2019). Fake news on Twitter during the 2016 US presidential election. Science, 363(6425), 374-378.

India Today. (2019). General Election 2019. Retrieved from https://www.indiatoday.in/elections

Jaffrelot, C. (2015). The Modi- centric BJP 2014 Election Campaign: New Techniques and Old Tactics. Contemporary South Asia 23(2): 155-61.

Jeffrey, R. (2000). India's Newspaper Revolution: Capitalism, Technology and the IndianlanguagePress, 1977- 1997. London: C. Hurst.

Kumar, S. (2015). Contagious memes, viral videos and subversive parody: The grammar of contention on the Indian web. International Communication Gazette, 77(3), pp.232-247.

Lazer, D. et al. (2018). The science of fake news, Science 359 (6380): 1094-1096.

Livemint. (2014). Narendra Modi's All India Radio chat show starts Friday. Retrieved from http://www.livemint.com/Politics/hdhhF1FzazRPQCrZegyr8I/Narendra-Modis-All-India-Radiochat-show-starts-Friday.html.

Livemint. (2018). How widespread is WhatsApp's usage in India? 
https://www.livemint.com/Technology/O6DLmIibCCV5luEG9XuJWL/How-widespread-is-

WhatsApps-usage-in-India.html

Mirchandani, M. (2018). Encouraging Counter-Speech by Mapping the Contours of Hate Speech on Facebook in India, https://www.orfonline.org/research/encouraging-counter-speech-bymapping-the-contours-of-hate-speech-on-facebook-in-india/ (last accessed 5.2.2019).

Moffitt, B. (2017). The Global Rise of Populism: Performance, Political Style, and Representation. Stanford: Stanford University Press.

Neuman, W.R. (2016). The Digital Difference: Media Technology and the Theory of CommunicationEffects. Cambridge, MA: Harvard University Press.

Neyazi, T.A., A. Kumar \& H. Semetko. (2016). Campaigns, Digital Media, and Mobilization in India.The International Journal of Press/ Politics 21(3): 398- 416.

Pal, J. (2015). Banalities turned viral: Narendra Modi and the political tweet. Television \& New Media, 16(4), 378-387.

Pal, J., P. Chandra \& V. Vydiswaran. (2016). Twitter and the Rebranding of Narendra Modi. Economic \& Political Weekly 51(8): 52- 60. 
Pal, J., Chandra, P., Chirumamilla, P., Kameswaran, V., Gonawela, A., Thawani, U., \&Dasgupta, P. (2017). Innuendo as Outreach:@narendramodi and the Use of Political Irony on Twitter. International Journal of Communication, 11: 4197-4218.

Pal, J., Mistree, D. and Madhani, T. (2018). A Friendly Neighborhood Hindu. In CeDEM Asia 2018: Proceedings of the International Conference for E-Democracy and Open Government; Japan 2018 (p. 91). Edition Donau-UniversitätKrems.

Parthasarathi, V.\&Mitra, A. (2017). Indian TV Anchors on Twitter: Technological Practice and Textual Form. In Jingrong Tong and Shih-Hung Lo (eds) Digital Technology and Journalism. Basingstoke: Palgrave Macmillan, pp. 263-289.

Price, L. 2016 (2nd ed.). The Modi Effect: Inside Narendra Modi’s Campaign to Transform India. London: Hodder.

Punathambekar, A. (2015). Satire, Elections, and Democratic Politics in Digital India. Television and New Media, vol. 16, no. 4, pp. 394-400.

Saxena, S. (2016). Mann Ki Baat: Radio as a Medium of Communication by the Indian Premier, Narendra Modi. Asian Politics \& Policy, 8(3), pp.520-524.

Sides, J., Tesler, M. and Vavreck, L. (2018). Identity crisis: The 2016 presidential campaign and the battle for the meaning of America. Princeton: Princeton University Press. 
Sinha, S.(2018). Fragile Hegemony: Modi, Social Media and Competitive Electoral Populism in India. International Journal of Communication, 11(2017), pp.4158-4180.

The Wire. (2018). Mute Modi: Why Is the PM Terrified of Holding Even a Single Press Conference? https://thewire.in/media/narendra-modi-press-conference.

Udupa, S. (2015). Internet Hindus: New India's Ideological Warriors. In Handbook of Religion and the Asian City: Aspiration and Urbanization in the Twenty- First Century, edited by P. van der Veer, 432- 49. Berkeley: University of California Press.

Venkatraman, S. (2017). Social Media in South India. London: UCL Press.

Woolley, S and Howard, P. (eds). (2018). Computational Propaganda: Political Parties, Politicians, and Political Manipulation on Social Media. Oxford: Oxford University Press. 
